\title{
The Fifth Case of End-Stage Renal Disease in the Same Family Due to Alport's Syndrome
}

\author{
Jamal Qasem Abumwais* \\ Ministry of Education and Higher Education, Jenin, Palestine
}

\begin{abstract}
Background: Alport's syndrome includes a group of heterogeneous inherited disorders involving the basement membranes of the kidney and may involve the cochlea and the eye. It is a progressive renal disease characterized by hematuria and progressive renal failure that is often accompanied by sensorineural deafness and/or ocular abnormalities mainly macular flecks and lenticonus. The heterogeneity in clinical and pathological manifestations , age at developing first symptoms, and age at developing renal failure are due to the differences in the mode of inheritance .The mode of inheritance is X-linked in $80 \%$, autosomal recessive in $15 \%$, and autosomal dominant in about $5 \%$ of reported cases.

Case presentation: I report the case of a 48 year-old female with a history of kidney insufficiency and hypertension since many years who was admitted to the emergency unit of The Martyr Dr. Khalil Sulaiman Hospital in Jenin city in 13/12/2012 suffering from fatigue, headache, nausea, vomiting, anorexia. Depending on laboratory tests, renal ultrasound image, physical examination, medical history, and family history, the patient was diagnosed with end- stage renal disease due to Alport's syndrome. Clinical examination revealed no hearing or ocular abnormalities.

Conclusion: From the clinical symptoms as the absence of hearing and ocular abnormalities and from the slow rate of progression to end-stage renal disease in this patient and the other affected members of the family which was presented at a relatively old age, it seems that the mode of inheritance of Alport's syndrome in this patient and other members of her family is autosomal dominant but genetic studies are needed to confirm this issue. The other members of this family must be screened for kidney functions even who looks like healthy especially that two of them are suffering from hypertension since many years.
\end{abstract}

Keywords: Alport's syndrome; Same family; Autosomal dominant; Jenin city

\section{Introduction}

Alport's syndrome encompasses a group of heterogeneous inherited disorders involving the basement membranes of the kidney and frequently involves the cochlea and the eye. These disorders are the result of mutations in COL4A3, COL4A4, and COL4A5 collagen biosynthesis genes. Mutations in any of these genes prevent the proper production or assembly of the type IV collagen network, which is an important structural component of basement membranes in the kidney, inner ear, and eye [1].

When mutations prevent the formation of type IV collagen fibers, the basement membranes of the kidneys are not able to filter waste products from the blood and create urine normally, allowing blood and protein into the urine. The abnormalities of type IV collagen in kidney basement membranes cause gradual scarring of the kidneys, eventually leading to kidney failure in many people with the disease [1].

Because it is a genetically heterogeneous nephropathy, Alport's syndrome may lead to end-stage renal disease (ESRD) in early adult life, sometimes; ESRD may be delayed until older ages. Alport's syndrome is often associated with sensorineural deafness and/or ocular abnormalities [2]. The mode of inheritance is X-linked in $80 \%$, autosomal recessive in $15 \%$, and autosomal dominant in $5 \%$ of reported cases [1].

Concerning the X-linked form of Alport's syndrome, more than 160 different mutations have yet been identified in the type IV collagen alpha 5 chains (COL4A5) gene, located at Xq22-24 head to head to the COL4A6 gene. The autosomal recessive form of Alport's syndrome is caused by mutations in the COL4A 3 and COL4A4 genes, located at 2q35-37 [3].

In contrast with the well-known X-linked phenotype, very little is known about the autosomal dominant form caused by mutations in
COL4A3 and COL4A4 in the chromosome region 2q35-q37 [2].

In a former study in a large Tunisian family, it was concluded that autosomal dominant Alport's syndrome follows a rare mode of inheritance and exhibits a milder phenotype than what is usually observed in classic X-linked Alport's syndrome, for example, the ocular or hearing abnormalities were very rare in this family [2].

Because it is genetically heterogeneous, Alport's syndrome exhibits variability in its clinical and pathological manifestations [4] While diagnosis of Alport's syndrome still depends on clinical and pathological evaluation, immunohistochemical and molecular genetics tools can augment diagnostic precision [4].

There are no specific therapies for Alport's syndrome. Renal transplantation is usually very successful. Occasional patients develop antiGMB nephritis of the allograft, almost always resulting in graft loss [5].

\section{Case Presentation}

A 48 year-old female with a history of kidney insufficiency and hypertension since many years was admitted to the emergency unit of The Martyr Dr.Khalil Sulaiman Hospital in Jenin city in 13/12/2012 suffering from fatigue, headache, nausea, vomiting, anorexia. Labs

*Corresponding author: Jamal Qasem Abumwais, Ministry of Education and Higher Education, Jenin, Palestine, Tel: 0097242518312, 00972599072538; E-mail: jamal_abumwais@yahoo.com

Received November 09, 2013; Accepted December 12, 2013; Published December 14, 2013

Citation: Abumwais JQ (2013) The Fifth Case of End-Stage Renal Disease in the Same Family Due to Alport's Syndrome. Genetics 2: 120. doi:10.4172/2161 1041.1000120

Copyright: ( 2013 Abumwais JQ. This is an open-access article distributed under the terms of the Creative Commons Attribution License, which permits unrestricted use, distribution, and reproduction in any medium, provided the original author and source are credited. 
Citation: Abumwais JQ (2013) The Fifth Case of End-Stage Renal Disease in the Same Family Due to Alport's Syndrome. Genetics 2: 120. doi:10.4172/2161-1041.1000120

Page 2 of 3

showed $\mathrm{Hb} 8.4 \mathrm{~g} / \mathrm{dl}$, RBCs $3.21 \mathrm{~m} / \mathrm{Ul}$, WBCs $9.8 \mathrm{k} / \mathrm{Ul}$, BUN 130.5 $\mathrm{mg} / \mathrm{dl}$, creatinine $9.2 \mathrm{mg} / \mathrm{dl}$. Urinalysis showed proteinuria and microhematuria. Kidney ultrasound showed bilateral shrunken kidneys accompanied by loss of corticomedullary differentiation.

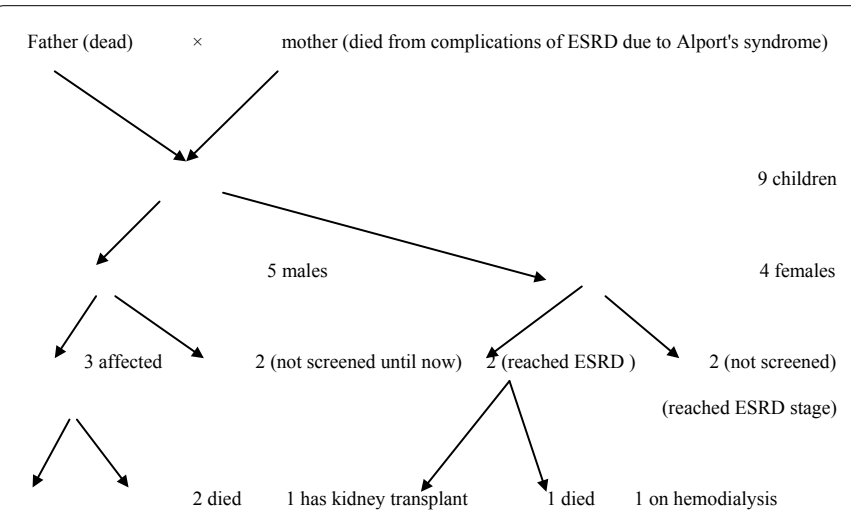

Figure 1: Family history of Alport's syndrome.

\begin{tabular}{|c|c|c|}
\hline Lab. Test & $\begin{array}{c}13 / 12 / 2012 \\
\text { (Before dialysis ) }\end{array}$ & $\begin{array}{c}\text { 21/12/2012 } \\
\text { (After dialysis ) }\end{array}$ \\
\hline WBC (K/UI) & 9.8 & 10.5 \\
\hline $\mathrm{RBC}(\mathrm{M} / \mathrm{UI})$ & 3.21 & 3.25 \\
\hline HGB (g/dl ) & 8.4 & 8.3 \\
\hline HCT ( \% ) & 29.1 & 26.8 \\
\hline $\mathrm{MCV}(\mathrm{FI})$ & 90.8 & 82.4 \\
\hline $\mathrm{MCH}(\mathrm{pg})$ & 26.2 & 25.5 \\
\hline $\mathrm{MCHC}(\mathrm{g} / \mathrm{dl})$ & 31.1 & 31 \\
\hline Platelets (K/UI) & 429 & 355 \\
\hline LYM (\%) & 22 & 22.8 \\
\hline NEUT (\%) & 60 & 58 \\
\hline Creatinine $(\mathrm{mg} / \mathrm{dl})$ & 9.2 & 5.9 \\
\hline Urea (mg/dl ) & 130.5 & 110 \\
\hline $\mathrm{Na}(\mathrm{mg} / \mathrm{l})$ & 140 & - \\
\hline $\mathrm{K}(\mathrm{mg} / \mathrm{l})$ & 4 & - \\
\hline Ca- free $(\mathrm{mg} / \mathrm{dl})$ & 1.26 & - \\
\hline $\mathrm{Cl}(\mathrm{mg} / \mathrm{dl})$ & 107 & - \\
\hline ALT (GPT) (U/L) & 26.2 & - \\
\hline AST (GOT) (U/L ) & 23.1 & - \\
\hline Total cholesterol (mg/dl) & 191.1 & - \\
\hline Total protein $(\mathrm{g} / \mathrm{dl})$ & 7.3 & - \\
\hline Albumin (g/dl) & 3.3 & - \\
\hline $\mathrm{HBsAg}$ & negative & - \\
\hline $\mathrm{HCV}$ & negative & - \\
\hline
\end{tabular}

Table 1: The laboratory investigations of the patient before initiation of hemodialysis and after one week of dialysis are summarized in table.
Depending on the laboratory findings, clinical investigation, ultrasound, medical history, and family history, the patient was diagnosed as a case of end-stage renal failure due to Alport's syndrome and initiated on hemodialysis 3 times weekly. (Figure 1) Family history of Alport's syndrome.

\section{Discussion}

This patient is the fifth case of end-stage renal disease due to Alport's syndrome in the same family whose members are nine $(5$ males and 4 females) in addition to the parents who died since long time. Until now, three brothers and one sister of the patient developed ESRD due to Alport's syndrome. The characteristics of the five patients of Alport's syndrome in this family are summarized in Tables 1 and 2.

The male to female ratio among patients in this family was $3: 2$. There are now 4 members of the family seem unaffected ( 2 females and 2 males), all of them are greater than 50 years old. They all need to be screened for kidney functions especially that two of them ( 2 females) suffers from hypertension since many years.

There were no ocular abnormalities in our patient. Ocular abnormalities was also absent in the other patients of the family except cataract in the two brothers and at an old age. The absence of ocular abnormalities have been described in patients of Alport's syndrome with autosomal dominant mode of inheritance in several studies $[2,6-8]$.

The patient has no deafness or any hearing abnormalities. Study of the history of the other patients in this family revealed that none of them suffered from deafness or any hearing abnormalities. Many studies about patients with autosomal dominant Alport's syndrome in many families revealed the absence of deafness among most the members of these families and sometimes the presence of mild - moderate deafness in few members of these families $[2,6,7]$.

From the results it is obvious that Alport's syndrome in this patient and the other patients of the family leads to end-stage renal failure lately at an old age. In addition, there were no hearing or ocular abnormalities in the patient and the other affected members (except cataract in 2 of the patients), so this family have a relatively mild phenotype of Alport's syndrome which is indicated by a slower rate of progression to ESRD than the most patients of X-linked Alport's syndrome. These findings are similar to that found in patients with autosomal dominant Alport's syndrome as revealed by many studies [2,6-8].

The clinical features of the patient and other members of her family may refer to an autosomal dominant Alport's syndrome but genetic studies are needed to confirm the mode of inheritance, in addition other members of the family must be screened for the disease especially who suffers from hypertension.

\begin{tabular}{|c|c|c|c|c|c|c|}
\hline Family member & Gender & $\begin{array}{l}\text { Age at diagnosis } \\
\text { of ESRD (years) }\end{array}$ & $\begin{array}{c}\text { Ocular } \\
\text { abnormalities }\end{array}$ & $\begin{array}{c}\text { Hearing } \\
\text { abnormalities }\end{array}$ & History of hypertension & Outcome \\
\hline 1 & male & 48 & none & none & yes & $\begin{array}{l}\text { died after } 3 \text { years of kidney transplant from } \\
\text { liver failure and cirrhosis }\end{array}$ \\
\hline 2 & female & 44 & none & none & yes & died at age of 57 after 13 years of hemodialysis \\
\hline 3 & male & 65 & $\begin{array}{c}\text { none } \\
\text { (except cataract) }\end{array}$ & none & yes & $\begin{array}{l}\text { died from complication of cancer and ESRD } \\
\text { after } 3 \text { months of hemodialysis }\end{array}$ \\
\hline 4 & male & 62 & $\begin{array}{c}\text { none } \\
\text { (except cataract) }\end{array}$ & none & yes & $\begin{array}{l}\text { underwent kidney transplantation taken from } \\
\text { his son since } 1 \text { year and still alive }\end{array}$ \\
\hline 5 & $\begin{array}{c}\text { Female } \\
\text { (the present patient) }\end{array}$ & 48 & none & none & Yes, since many years & Initiated on hemodialysis on $13 / 12 / 2012$ \\
\hline
\end{tabular}

Table 2: Summary of the identified clinical findings in affected members of the patient's family. 
Citation: Abumwais JQ (2013) The Fifth Case of End-Stage Renal Disease in the Same Family Due to Alport's Syndrome. Genetics 2: 120. doi:10.4172/2161-1041.1000120

Page 3 of 3

\section{Conclusion}

The slow progression of the patient's case towards end-stage renal disease, the relatively old age at developing end-stage renal disease in the patient's family, and the relatively mild phenotypic type of Alport's syndrome (absence of hearing or ocular abnormalities) in this family points to an autosomal dominant type of inheritance, but to confirm this issue, genetic studies must be done for the alive members of this family.

\section{Acknowledgements}

I am greatly indebted to Palestinian Ministry of Health and to Dr. Mohammad Abu-Ghali, the head master of The Martyr Dr. Khalil Sulaiman Hospital who gave me the chance to do this study. Special thanks to all the physicians and nurse staff of the kidney unit and to all the workers in the laboratory unit. I would like also to thank the patient for her assistance.

\section{References}

1. Oni AO, Eweka AO, Otuaga PO, Odia JO (2009) Alport's syndrome. Saudi J Kidney Dis Transpl 20: 1087-1089.
2. Kharrat M, Makni S, Makni K, Kammoun K, Charfeddine K, et al. (2006) Autosomal dominant Alport's syndrome: study of a large Tunisian family. Saud J Kidney Dis Transpl 17: 320-325.

3. Lemmink HH, Schröder CH, Monnens LA, Smeets HJ (1997) The clinica spectrum of type IV collagen mutations. Hum Mutat 9: 477-499.

4. Kashtan CE (1995) Clinical and molecular diagnosis of Alport syndrome. Proc Assoc Am Physicians 107: 306-313.

5. Kashtan CE (1999) Alport syndrome. An inherited disorder of renal, ocular, and cochlear basement membranes. Medicine (Baltimore) 78: 338-360.

6. Ciccarese M, Casu D, Ki Wong F, Faedda R, Arvidsson S, et al. (2001) Identification of a new mutation in the alpha4(IV) collagen gene in a family with autosomal dominant Alport syndrome and hypercholesterolaemia. Nephrol Dial Transplant 16: 2008-2012.

7. Jefferson JA, Lemmink HH, Hughes AE, Hill CM, Smeets HJ, et al. (1997) Autosomal dominant Alport syndrome linked to the type IV collage alpha 3 and alpha 4 genes (COL4A3 and COL4A4). Nephrol Dial Transplant 12: 1595-1599.

8. Colville D, Wang YY, Jamieson R, Collins F, Hood J, et al. (2000) Absence of ocular manifestations in autosomal dominant Alport syndrome associated with haematological abnormalties. Ophthalmic Genet 21: 217-225. 